\title{
Phosphatidylinositol 3-Kinase and Akt Protein Kinase Are Necessary and Sufficient for the Survival of Nerve Growth Factor- Dependent Sympathetic Neurons
}

\author{
Robert J. Crowder and Robert S. Freeman \\ Department of Pharmacology and Physiology, University of Rochester, School of Medicine, Rochester, New York 14642
}

Recent studies have suggested a role for phosphatidylinositol (PI) 3-kinase in cell survival, including the survival of neurons. We used rat sympathetic neurons maintained in vitro to characterize the potential survival signals mediated by PI 3-kinase and to test whether the Akt protein kinase, a putative effector of PI 3-kinase, functions during nerve growth factor (NGF)mediated survival. Two PI 3-kinase inhibitors, LY294002 and wortmannin, block NGF-mediated survival of sympathetic neurons. Cell death caused by LY294002 resembles death caused by NGF deprivation in that it is blocked by a caspase inhibitor or a CAMP analog and that it is accompanied by the induction

The survival of developing neurons requires extracellular signals that actively prevent programmed cell death. These signals are provided, in part, by neurotrophic factors such as nerve growth factor (NGF) (Oppenheim, 1991). Sympathetic neurons from the rat superior cervical ganglion (SCG) provide a well characterized model for studying NGF-mediated neuronal survival. If NGF is withdrawn from cultured sympathetic neurons, they undergo apoptosis (Deckwerth and Johnson, 1993; Edwards and Tolkovsky, 1994). Similarly, the SCG from mice lacking NGF (Crowley et al., 1994) or its receptor, TrkA (Smeyne et al., 1994), fail to develop because of massive neuronal death. In contrast, adding exogenous NGF in vivo prevents the naturally occurring death of sympathetic neurons during development (Hendry and Campbell, 1976). Thus, cultures of dissociated sympathetic neurons provide a useful in vitro model for studying neurotrophic factor dependence.

Although the function of NGF as a survival-promoting factor is well established, the mechanisms responsible for NGF-mediated survival remain, in large part, uncharacterized. NGF affects neuronal survival and differentiation by binding to and activating the TrkA tyrosine kinase receptor (Barbacid, 1994). Once activated,

\footnotetext{
Received Oct. 20, 1997; revised Jan. 27, 1998; accepted Feb. 4, 1998.

This work was supported in part by a Lucille P. Markey Charitable Trust award to the University of Rochester, the Paul Stark Endowment at the University of Rochester, and National Institutes of Health Grant NS34400. R.J.C. was supported by a National Institutes of Health predoctoral training grant. We thank Anke Klippel for generously providing the $\mathrm{p} 110^{*}$ and $\mathrm{p} 110^{*} \Delta$ kin expression plasmids, Richard Roth for the gift of pECE-myr-Akt and pECE-A2myr-Akt plasmids, Jill Johnson and Edward Sausville for flavopiridol, and Thomas Franke and David Kaplan for anti-Akt-CT serum. We also thank Paul Coffer for the pSG5-HA-PKB K179A plasmid, Masato Kasuga for plasmids containing $\Delta$ p85 cDNAs, and Eugene Johnson and Patricia Osborne for generously providing neutralizing anti-NGF antiserum. We are grateful to Robert Gross for the use of his micropipette puller and Leah Larocque for the preparation of collagen and tissue culture reagents.

Correspondence should be addressed to Dr. Robert S. Freeman, Department of Pharmacology and Physiology, University of Rochester, School of Medicine, 601 Elmwood Avenue, Rochester, NY 14642.

Copyright (C) 1998 Society for Neuroscience $\quad 0270-6474 / 98 / 182933-11 \$ 05.00 / 0$
}

of c-jun, c-fos, and cyclin D1 mRNAs. Treatment of neurons with NGF activates endogenous Akt protein kinase, and LY294002 or wortmannin blocks this activation. Expression of constitutively active Akt or PI 3-kinase in neurons efficiently prevents death after NGF withdrawal. Conversely, expression of dominant negative forms of PI 3-kinase or Akt induces apoptosis in the presence of NGF. These results demonstrate that PI 3-kinase and Akt are both necessary and sufficient for the survival of NGF-dependent sympathetic neurons.

Key words: apoptosis; phosphatidylinositol 3-kinase; NGF; neuronal survival; Akt; neurotrophic factor
TrkA autophosphorylates specific tyrosine residues within its intracellular domain (Kaplan et al., 1991; Klein et al., 1991). The phosphorylated tyrosines serve as protein interaction sites for several signaling molecules, including SHC, phospholipase C- $\gamma$, and phosphatidylinositol (PI) 3-kinase (Ohmichi et al., 1991; Carter and Downes, 1992; Raffioni and Bradshaw, 1992; Soltoff et al., 1992; Obermeier et al., 1993). The consequences of TrkA activation include Shc/Grb2/Sos-dependent activation of Ras and the subsequent activation of mitogen-activated protein (MAP) kinases, phospholipase $\mathrm{C}-\gamma$-mediated production of diacylglycerol and inositol trisphosphate, and PI 3-kinase-mediated production of $3^{\prime}$-phosphorylated phosphoinositides (Kaplan and Stephens, 1994).

Although previous studies have focused on Ras and MAP kinases in NGF-mediated survival (Borasio et al., 1989, 1993; Ferrari and Greene, 1994; Nobes and Tolkovsky, 1995; Xia et al., 1995; Yao and Cooper, 1995; Creedon et al., 1996; Virdee and Tolkovsky, 1996), several recent reports suggest that PI 3-kinase functions in the survival pathways initiated by certain growth factors and survival-promoting agents. Using the PI 3-kinase inhibitors wortmannin and LY294002, Yao and Cooper (1995) reported that the inhibition of PI 3-kinase activity induces apoptosis in PC12 cells in the presence of NGF. This observation since has been extended to other immortalized cell lines, particularly those dependent on insulin-like growth factor-1 (IGF-1) for survival. For example, in Rat-1 fibroblasts PI 3-kinase inhibitors block IGF-1-mediated protection from apoptosis induced by UV irradiation (Kulik et al., 1997) and serum- or IGF-1-mediated protection from c-Myc-induced apoptosis (Kauffmann-Zeh et al., 1997; Kennedy et al., 1997). Similarly, PI 3-kinase inhibitors block IGF-1-mediated survival of PC12 cells (Parrizas et al., 1997). Consistent with these results, a function for PI 3-kinase has been demonstrated recently in the survival of cerebellar granule neurons mediated by IGF-1 or by potassium depolarization (D'Mello et al., 1997; Dudek et al., 1997; Miller et al., 1997). 
To characterize further the role of PI 3-kinase in the survival of primary neurons, we have used NGF-dependent sympathetic neurons to compare the cell death caused by inhibitors of PI 3-kinase with that caused by NGF withdrawal. We also have tested whether a putative effector of PI 3-kinase, the serine/ threonine protein kinase Akt (also known as protein kinase B or Rac protein kinase) (Burgering and Coffer, 1995; Franke et al., 1995; Kohn et al., 1995), functions in the survival of NGFdependent neurons.

\section{MATERIALS AND METHODS}

Cycloheximide, actinomycin D, wortmannin, and chlorophenylthiocAMP (cpt-cAMP) were purchased from Sigma (St. Louis, MO); bocaspartyl(OMe)-fluoromethylketone (BAF) was obtained from Enzyme Systems Products (Dublin, CA); LY294002 was obtained from Biomol Research Laboratories (Plymouth Meeting, PA). Flavopiridol was provided by Drs. J. Johnson and E. Sausville (Drug Synthesis and Chemistry Branch, National Cancer Institute, Bethesda, MD).

Cell culture. Primary cultures of sympathetic neurons were prepared from SCG of embryonic day 21 rats as previously described (Martin et al., 1992) except that a preplating step was included to minimize nonneuronal cells. For preplating, SCG neurons were dissociated and resuspended in NGF-containing media (AM50 medium) consisting of 90\% Minimum Essential Media (MEM; Life Technologies, Gaithersburg, MD), $10 \%$ FBS (Sigma), $2 \mathrm{~mm}$ glutamine, $20 \mu \mathrm{M}$ uridine, and $20 \mu \mathrm{M}$ fluorodeoxyuridine (to inhibit the proliferation of non-neuronal cells), $100 \mathrm{U} / \mathrm{ml}$ penicillin, $100 \mu \mathrm{g} / \mathrm{ml}$ streptomycin, and $50 \mathrm{ng} / \mathrm{ml} \mathrm{NGF}$ (Harlan Bioproducts, Madison, WI). The cell suspension was filtered through a Nitex filter (size 3-20/14; Tetko, Briarcliff Manor, NY) and plated onto Primaria tissue culture dishes (Becton Dickinson, Lincoln Park, NJ) for a period of 1-2 hr. Nonadherent cells were collected and concentrated by centrifugation $(10 \mathrm{~min}$ at $450 \times \mathrm{g})$ and plated onto $60 \mathrm{~mm}$ collagencoated dishes for reverse transcription (RT)-PCR $(25,000 \mathrm{cells} / \mathrm{dish})$ and kinase assays $(125,000$ cells/dish), onto collagen-coated two-well chamber slides (Nalge Nunc, Naperville, IL) for viability measurements (3000 cells/well), or onto poly-L-ornithine-coated (Sigma) and laminin-coated (Collaborative Biomed, Bedford, MA) $35 \mathrm{~mm}$ glass-bottomed dishes (MatTek, Ashland, MA) for microinjection (3000 cells/dish).

For NGF deprivation studies the neurons were switched into a medium identical to that described above except that it lacked NGF and contained neutralizing anti-NGF antiserum (AM0 medium). For potassium depolarization treatments, neurons cultured for $5 \mathrm{~d}$ in AM50 were switched into high $\mathrm{K}^{+}$medium consisting of MEM supplemented to $50 \mathrm{mM} \mathrm{KCl}$, $10 \%$ FBS, 2 mM glutamine, $20 \mu \mathrm{M}$ uridine, $20 \mu \mathrm{m}$ fluorodeoxyuridine, $100 \mathrm{U} / \mathrm{ml}$ penicillin, $100 \mu \mathrm{g} / \mathrm{ml}$ streptomycin, and neutralizing anti-NGF antiserum for $2 \mathrm{~d}$ before drug treatment.

Terminal deoxynucleotidyl transferase-mediated dUTP-digoxigenin nick end labeling (TUNEL) analysis. Neurons plated on collagen-coated twowell chamber slides were treated with $100 \mu \mathrm{M}$ LY294002 in AM50 for 72 $\mathrm{hr}$. The cells were fixed in fresh $4 \%$ paraformaldehyde in PBS for $15 \mathrm{~min}$, permeabilized with $0.3 \%$ Triton X-100/PBS for $10 \mathrm{~min}$, rinsed in PBS, and subjected to the TUNEL assay (Gavrieli et al., 1992). For the terminal deoxynucleotidyl-transferase reaction, neurons were overlaid with a reaction solution containing $1 \times$ terminal deoxynucleotidyltransferase reaction buffer, $1 \mathrm{mM} \mathrm{CoCl}, 0.25 \mathrm{U} / \mu \mathrm{l}$ terminal deoxynucleotidyl-transferase (Boehringer Mannheim, Indianapolis, IN), and $6 \mu \mathrm{M}$ digoxigenin-11-dUTP (Boehringer Mannheim) and then incubated for $90 \mathrm{~min}$ at $37^{\circ} \mathrm{C}$. Neurons were rinsed in PBS, incubated in blocking buffer (2\% BSA and 5\% goat serum in PBS) for $1 \mathrm{hr}$, and incubated overnight at $4^{\circ} \mathrm{C}$ with FITC-conjugated anti-digoxigenin antibodies (Oncor, Gaithersburg, MD) diluted 1:2 in blocking buffer. Then the neurons were rinsed in PBS and stained with $2 \mu \mathrm{g} / \mathrm{ml}$ Hoechst 33342 (Molecular Probes, Eugene, OR) in PBS for 5 min to visualize the nuclei of cells. After two additional rinses with PBS, the slides were covered with glass coverslips, using a mounting solution of $50 \%$ glycerol and $0.1 \%$ phenylenediamine in PBS, and then visualized by fluorescence microscopy with a Nikon Diaphot 300 inverted microscope.

Quantitation of neuronal viability. Equal numbers of neurons plated on collagen-coated two-well chamber slides were subjected to the appropriate treatments and then were fixed with fresh $4 \%$ paraformaldehyde/PBS overnight at $4^{\circ} \mathrm{C}$. Neurons were rinsed in PBS and stained briefly with $0.1 \%$ crystal violet (EM Science, Gibbstown, NJ). The neurons were destained in $\mathrm{H}_{2} \mathrm{O}$, dehydrated in increasing ethanol concentrations, transferred to xylene (Fisher Scientific, Pittsburgh, PA), and finally coverslipped by using Pro-Texx mounting media (Baxter Diagnostics, Deerfield, IL). Neurons staining darker than debris with a clearly defined cellular outline and a well defined nucleus were scored as viable. For each experimental treatment four fields of cells from each of three to four wells were counted under a $20 \times$ objective, and the average number of viable cells per field was determined. This was normalized to the average number of viable neurons in parallel nontreated control cultures. The results reported for each condition represent the means and errors (where appropriate) obtained from two to four independent experiments.

RT-PCR analysis. Preparation of cDNAs and analysis of gene expression in SCG neurons treated with LY294002 were essentially the same as those described for NGF-deprived neurons (Freeman et al., 1994). Preplated cultures $(25,000$ neurons plated per time point) were maintained in AM50 for $5 \mathrm{~d}$ and then treated with LY294002 diluted to a final concentration of $100 \mu \mathrm{M}$ in AM50 for the indicated intervals. Polyadenylated RNA was isolated by direct hybridization to oligo-dT-cellulose beads, as described by the manufacturer (QuickPrep Micro mRNA Purification Kit, Pharmacia Biotech, Piscataway, NJ). One-half of the recovered mRNA was reverse-transcribed by using Moloney murine leukemia virus reverse transcriptase (Superscript II RT; Life Technologies) and random hexamers $(16 \mu \mathrm{M})$ as primers in $20 \mu \mathrm{l}$ reactions containing $50 \mathrm{~mm}$ Tris, $\mathrm{pH} 8.3,40 \mathrm{~mm} \mathrm{KCl}, 10 \mathrm{~mm}$ DTT, $6 \mathrm{~mm} \mathrm{MgCl}_{2}$, 20 U RNAsin (Promega, Madison, WI), and $500 \mu \mathrm{M}$ each dATP, dCTP, dGTP, and dTTP (Boehringer Mannheim). After a $1 \mathrm{hr}$ incubation at $42^{\circ} \mathrm{C}$, the reaction was terminated by adding $80 \mu \mathrm{l}$ of $\mathrm{H}_{2} \mathrm{O}$ and heating the reaction for $5 \mathrm{~min}$ at $95^{\circ} \mathrm{C}$. Specific cDNAs were amplified in $30 \mu \mathrm{l} \mathrm{PCR}$ reactions containing the appropriate primer pairs ( $0.6 \mu \mathrm{M}$ each), $1 \times \mathrm{Taq}$ polymerase buffer, $1 \mathrm{U} \mathrm{Taq}$ polymerase, $1.5 \mathrm{mM} \mathrm{MgCl}_{2}, 50 \mu \mathrm{M} \mathrm{dCTP}$, $100 \mu \mathrm{M}$ each dATP, dGTP, and dTTP, $6 \mu \mathrm{Ci}\left[\alpha^{32} \mathrm{P}\right]$ dCTP (DuPont NEN, Boston, MA), and $0.6 \mu \mathrm{l}$ cDNA synthesized in the RT reaction. PCR parameters were $1 \mathrm{~min}$ at $94^{\circ} \mathrm{C}, 1 \mathrm{~min}$ at $60^{\circ} \mathrm{C}$, and $2 \mathrm{~min}$ at $72^{\circ} \mathrm{C}$ for $16-28$ cycles, followed by a final 10 min incubation at $72^{\circ} \mathrm{C}$. Reaction products were separated by electrophoresis and analyzed by autoradiography and PhosphorImager analysis (Molecular Dynamics, Sunnyvale, CA). Control experiments to determine the linear range of PCR amplification and to verify the identity of amplified products were as described previously, as were the sequences of oligonucleotide primers (Estus et al., 1994; Freeman et al., 1994).

Plasmid expression vectors. Expression vectors for the Escherichia coli $\beta$-galactosidase (LacZ) gene, p110*, and $\mathrm{p} 110^{*} \Delta$ kin under the control of the human cytomegalovirus immediate early gene promoter have been described previously (Greenlund et al., 1995a; Hu et al., 1995). Myr-Akt and A2myr-Akt cDNAs (Kohn et al., 1996b) were cloned behind the cytomegalovirus promoter in the plasmid pcDNA3 (Invitrogen, San Diego, CA) by inserting the KpnI to $X b a \mathrm{I}$ fragments from pECE-myrAkt or pECE-A2myr-Akt between the KpnI and $X b a \mathrm{I}$ sites of pcDNA3. The $\Delta \mathrm{p} 85$ cDNA was removed from pGEX- $\Delta \mathrm{p} 85$ (Kotani et al., 1994) as a BamHI to EcoRI fragment and inserted between the BamHI and EcoRI sites in pcDNA3. The rat AH-Akt-Flag construct, encoding amino acids $1-148$ of rat Akt followed by the Flag epitope, was generated by pfu polymerase (Stratagene, La Jolla, CA) amplification from rat SCG cDNA, using a $5^{\prime}$ primer (5'-GCG GAT CCA CCA TGA ACG ACG TAG CCA TTG TG-3') containing a BamHI site, a consensus transcription start site, and nucleotides $1-21$ of the rat Akt open reading frame (Konishi et al., 1994). The 3' primer (5'-GCG AAT TCT CAC TTG TCA TCG TCG TCC TTG TAG TCG TTC ATG GTC ACA CGG TG-3') consisted of an EcoRI site, nucleotides 427-444 of the rat Akt open reading frame, and sequences corresponding to the Flag epitope. The PCR-generated fragment was ligated into the BamHI and EcoRI sites of pcDNA3. DNA sequencing revealed that the construct was correct. AktK179A-pcDNA3 was constructed by ligating an EcoRI/ Klenow-filled-BglII fragment from pSG5 HA-PKB K179A (Burgering and Coffer, 1995), containing an Akt kinase-inactive mutant cDNA, into the EcoRI and EcoRV sites of pcDNA3.

Intracellular microinjections. Neurons plated on poly-L-ornithine and laminin-coated glass-bottomed $35 \mathrm{~mm}$ dishes were microinjected by using a Nikon Diaphot 300 inverted microscope equipped with a PLI-100 picoinjector (Medical Systems, Greenvale, NY) and a Narishige micromanipulator (Nikon-Narishige, Tokyo, Japan). Microinjection needles were pulled from glass capillaries with a horizontal micropipette puller (Sutter Instruments, Novato, CA). For experiments in which neuronal survival was evaluated, expression plasmids were diluted to a final concentration of $50-100 \mu \mathrm{g} / \mathrm{ml}$ in $\mathrm{KP}_{\mathrm{i}}$ buffer $(100 \mathrm{~mm} \mathrm{KCl}$ and $10 \mathrm{~mm}$ 
potassium phosphate, $\mathrm{pH} 7.4$ ) containing $4 \mathrm{mg} / \mathrm{ml}$ rhodamine-dextran $\left(10 K_{\mathrm{D}}\right.$; Sigma) to mark the injected cells. For microinjections, neurons were maintained in AM50 for 5-6 d and then transferred to Leibovitz's L-15 medium (Life Technologies) immediately before injection. Approximately 100-125 neurons per dish were injected directly into the nucleus. After microinjection, neurons were returned to AM50 for $12-15 \mathrm{hr}$ to allow for the expression of the cDNA. Then the number of injected (rhodamine-positive) neurons was determined before NGF deprivation was initiated. Approximately $48 \mathrm{hr}$ later the cells were stained with the DNA-binding dye Hoechst 33342 in L-15 medium and evaluated for survival. Neuronal viability was assessed by counting the number of rhodamine-positive cells that were phase-bright with smooth and intact neurites, a discernible nucleus, and diffuse and homogenous chromatin. A small percentage of injected neurons did not regain membrane integrity and died within a few hours of injection; these neurons did not affect subsequent analyses. The percentage of survival was equal to the number of viable cells remaining after NGF deprivation (determined as described above) divided by the number of rhodamine-positive cells counted before NGF withdrawal. For each plasmid the results reported were derived from at least three independent experiments involving a minimum of 200 injected neurons per plasmid per experiment. In all microinjection experiments a blinded observer accessed cell viability.

Immunofluorescence. Expression of $\mathrm{p} 110^{*}, \mathrm{p} 110^{*} \Delta \mathrm{kin}, \Delta \mathrm{p} 85$, myr-Akt, A2myr-Akt, AH-Akt·Flag, and AktK179A in injected neurons was confirmed by using indirect immunofluorescence. In each case the neurons were microinjected with solutions containing $50 \mu \mathrm{g} / \mathrm{ml}$ expression vector DNA and $2 \mathrm{mg} / \mathrm{ml}$ lysine-fixable tetramethylrhodamine-dextran dye (Molecular Probes) in $\mathrm{KP}_{\mathrm{i}}$ buffer. Injected neurons were incubated $\sim 15$ $\mathrm{hr}$ in AM50 and then fixed in fresh 4\% paraformaldehyde in PBS for 15 $\mathrm{min}$ at room temperature. After being permeabilized for $10 \mathrm{~min}$ in fixative containing $0.3 \%$ Triton $\mathrm{X}-100$, the neurons were incubated for 45-60 min in blocking buffer containing $1 \%$ BSA, 5\% goat serum, and $0.05 \%$ Tween-20 in PBS. Then the cells were incubated with the appropriate primary antibody diluted in blocking buffer for $2 \mathrm{hr}$ at room temperature. For the detection of p110 molecules, mouse monoclonal antibody 9E10 (Sigma) against the c-Myc epitope was used at a 1:500 dilution. Myr-Akt and A2myr-Akt were detected with the T7·Tag mouse monoclonal antibody (Novagen, Madison, WI) diluted 1:100. AktK179A was detected with anti-Akt CT serum (Franke et al., 1995) diluted 1:400, whereas AH-Akt·Flag was detected with the anti-Flag M2 monoclonal antibody (Kodak IBI, New Haven, CT) at a 1:300 dilution. An anti-rat PI 3-kinase polyclonal antibody that recognizes the p85 subunit (Upstate Biotechnology, Lake Placid, NY) was used to detect $\Delta$ p85. FITCconjugated goat anti-mouse (for detecting $\mathrm{p} 110^{*}, \mathrm{p} 110^{*} \Delta \mathrm{kin}$, myr-Akt, $\mathrm{A} 2 \mathrm{myr}-\mathrm{Akt}$, and AH-Akt-Flag molecules) or goat anti-rabbit (for detecting AktK179A and $\Delta \mathrm{p} 85$ ) secondary antibodies (Jackson Laboratories, Bar Harbor, ME), diluted 1:100 in blocking buffer, were applied to the neurons for $1 \mathrm{hr}$ at room temperature. After being rinsed in PBS, the neurons were mounted under glass coverslips and viewed by fluorescence microscopy. For each DNA tested, $85-90 \%$ of microinjected neurons expressed the appropriate protein. Use of the lysine-fixable dye in these experiments allowed for the identification of injected cells after fixation but resulted in significant toxicity to neurons after 2-3 d. Therefore, this dye was not used in survival experiments.

Akt kinase assays. SCG neurons were plated on collagen-coated $60 \mathrm{~mm}$ dishes (125,000 neurons/dish) and maintained in AM50 medium for 6-8 $\mathrm{d}$ before being deprived of NGF by incubation in AM0 medium. After 10 hr of NGF deprivation, the medium was replaced with either fresh AM0 ("minus NGF" samples) or AM50 ("plus NGF" samples) for an additional $15 \mathrm{~min}$. For testing the effects of PI 3-kinase inhibitors on Akt activation, we pretreated neurons with LY294002 or wortmannin during the final 45 min of NGF deprivation before exposing them to AM50 medium containing the same inhibitor. Cleared cell lysates were prepared by incubating cells in NP-40 lysis buffer [containing (in mM) 20 Tris, pH 7.4, $137 \mathrm{NaCl}, 1$ EDTA, $20 \mathrm{NaF}, 1 \mathrm{Na}_{4} \mathrm{P}_{2} \mathrm{O}_{7}, 1 \mathrm{Na}_{3} \mathrm{VO}_{4}$, and 1 PMSF with $1 \%$ NP-40, $10 \%$ glycerol, $5 \mu \mathrm{g} / \mathrm{ml}$ aprotinin, and $5 \mu \mathrm{g} / \mathrm{ml}$ leupeptin] for $30 \mathrm{~min}$ at $4^{\circ} \mathrm{C}$ and then by centrifuging the lysates $(14,000 \times g)$ for $5 \mathrm{~min}$ at $4^{\circ} \mathrm{C}$. Lysates were preabsorbed for $20 \mathrm{~min}$ with $20 \mu \mathrm{l}$ of a $50 \%$ slurry of protein A-Sepharose (Pharmacia Biotech), centrifuged briefly to pellet the protein A beads, and then incubated with a 1:300 dilution of anti-Akt-CT serum and $40 \mu \mathrm{l}$ of protein A-Sepharose beads for $3 \mathrm{hr}$ at $4^{\circ} \mathrm{C}$ with constant rotation. The immune complexes were washed three times with lysis buffer, once with ice-cold $\mathrm{H}_{2} \mathrm{O}$, and twice with kinase buffer [containing (in mM) 20 HEPES, pH 7.4, $10 \mathrm{MgCl}_{2}, 10$ $\mathrm{MnCl}_{2}, 1 \mathrm{DTT}$, and 0.2 EGTA with $5 \mu \mathrm{M}$ ATP] before being incubated for $30 \mathrm{~min}$ at $30^{\circ} \mathrm{C}$ in $30 \mu \mathrm{l}$ of kinase buffer containing $1 \mu \mathrm{M}$ PKA inhibitor (Sigma), $0.1 \mathrm{mg} / \mathrm{ml}$ histone H2B (Boehringer Mannheim), and $10 \mu \mathrm{C}\left[\gamma^{-}{ }^{32} \mathrm{P}\right] \mathrm{ATP}$ (DuPont NEN). Reactions were terminated by briefly pelleting the immune complexes, adding SDS-PAGE sample buffer to the supernatant, and boiling the samples for $5 \mathrm{~min}$. Phosphorylation of histone H2B was analyzed by $15 \%$ SDS-PAGE, followed by autoradiography and PhosporImager analysis.

\section{RESULTS}

\section{Characterization of the death of NGF-dependent sympathetic neurons caused by inhibitors of PI 3-kinase}

Postmitotic sympathetic neurons isolated from neonatal rat SCG and maintained in vitro are homogenous in their requirement for NGF such that all neurons die within 48-72 hr after NGF withdrawal (Martin et al., 1988; Deckwerth and Johnson, 1993). Cell death can be induced in the presence of NGF by treating neurons with the selective PI 3-kinase inhibitor LY294002 (Fig. 1). LY294002-treated neurons have shrunken cell soma and fragmented neurites and frequently contain one or more compact spheres of condensed chromatin in their nuclei, in contrast to the uniformly dispersed chromatin present in the nuclei of nontreated neurons (Fig. 1B,E). Many of the nuclei are labeled by the TUNEL assay, indicating the presence of DNA strand breaks (Fig. $1 F$ ). These characteristics of LY294002-treated neurons are indistinguishable from those that typify apoptosis caused by NGF deprivation (Deckwerth and Johnson, 1993; Edwards and Tolkovsky, 1994).

Despite these morphological similarities, SCG neurons treated with LY294002 die more slowly than neurons deprived of NGF (Fig. $2 A$ ). In control cultures the removal of NGF caused $\sim 60 \%$ death by $24 \mathrm{hr}$ and $>75 \%$ death by $48 \mathrm{hr}$. In contrast, $34 \%$ of neurons treated with $100 \mu \mathrm{M}$ LY294002 in the presence of NGF died by $48 \mathrm{hr}$, with $85 \%$ dying by $96 \mathrm{hr}$. Moreover, death of LY294002-treated neurons commences only after at least $24 \mathrm{hr}$, as compared with a lag period of 15-18 hr for NGF deprivationinduced death (Deckwerth and Johnson, 1993). In contrast to these results, death of cerebellar granule neurons caused by LY294002 treatment occurs at the same rate as death caused by the withdrawal of survival factors (Miller et al., 1997). Thus, the increased rate of death caused by NGF withdrawal relative to LY294002 treatment may indicate that factors other than the inactivation of PI 3-kinase are rate-determining for the death of sympathetic neurons after NGF removal.

Under our experimental conditions LY294002 inhibited NGFmediated survival at concentrations as low as $10 \mu \mathrm{M}$, with a $50 \%$ inhibitory concentration $\left(\mathrm{IC}_{50}\right)$ of $\sim 30 \mu \mathrm{M}$ (Fig. $2 \mathrm{~B}$ ). Although the $\mathrm{IC}_{50}$ of LY294002 for blocking PI 3-kinase activity in vitro is $1.4 \mu \mathrm{M}$ (Vlahos et al., 1994), concentrations ranging from 10 to $100 \mu \mathrm{M}$ often are necessary to inhibit PI 3-kinase in intact cells (Vlahos et al., 1994; Yao and Cooper, 1996; Miller et al., 1997). Wortmannin, another PI 3-kinase inhibitor (Yano et al., 1993), also blocked the survival-promoting effects of NGF on sympathetic neurons (data not shown); the time course was similar to that of LY294002 and death was virtually complete at a concentration $(100 \mathrm{~nm})$ previously shown to be necessary for efficiently blocking PI 3-kinase activity and inducing DNA fragmentation in NGF-treated PC12 cells (Yao and Cooper, 1995). The ability of two structurally distinct inhibitors of PI 3-kinase to block NGFmediated survival strongly implicates PI 3-kinase, or a PI 3-kinase-related enzyme, as a necessary transducer of the survival signals initiated by NGF in primary neurons.

A variety of pharmacological agents can inhibit the death of 

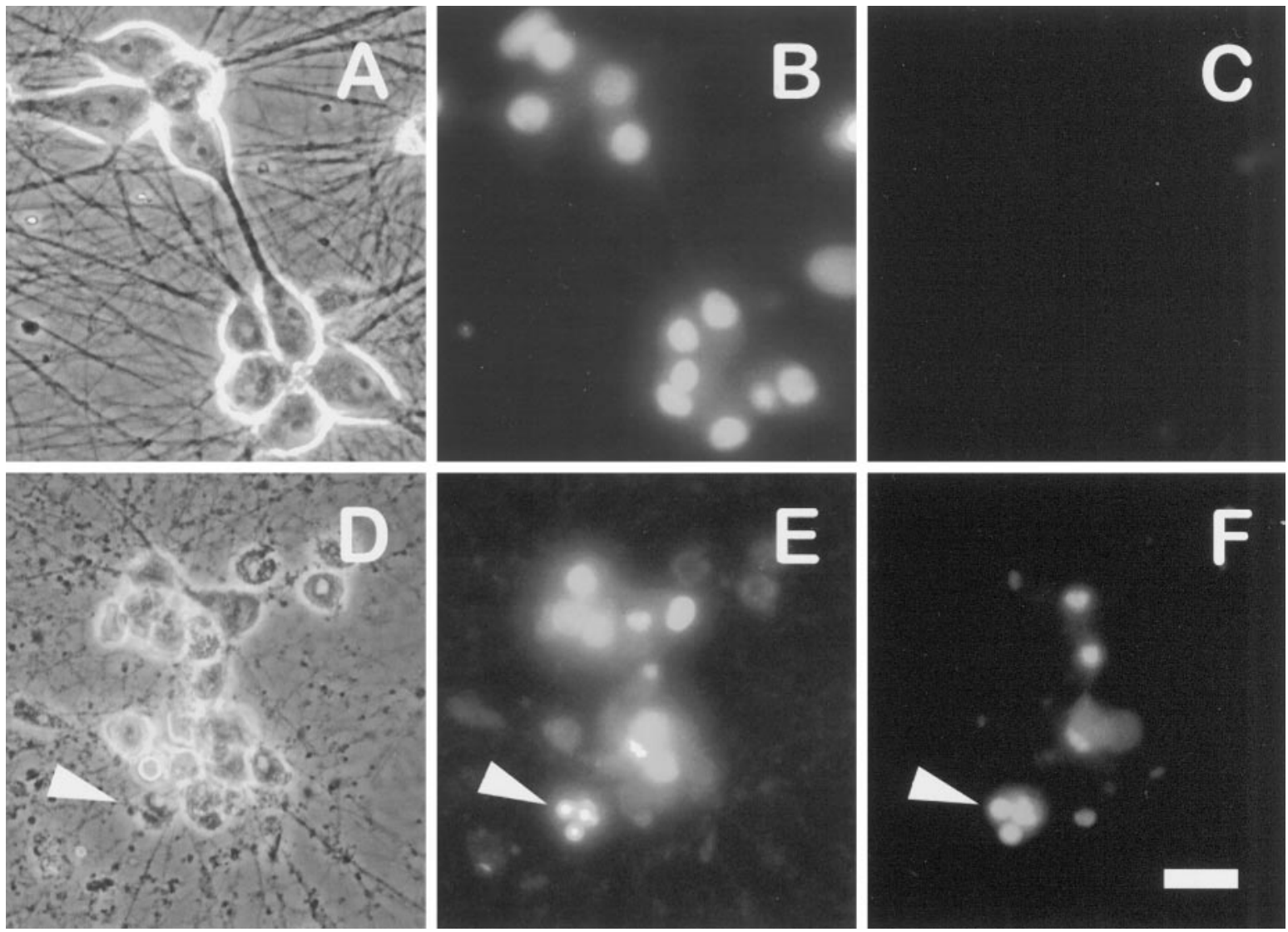

Figure 1. LY294002 kills sympathetic neurons in a manner that morphologically resembles NGF deprivation. The 5 d neuronal cultures were treated with or without $100 \mu \mathrm{M} \mathrm{LY} 294002$ in AM50 media. Approximately $72 \mathrm{hr}$ later the neurons were fixed, processed for TUNEL analysis and Hoechst staining, and photographed. $A-C$ show phase-contrast, Hoechst-stained chromatin, and TUNEL-labeled views, respectively, from the same field of NGF-maintained (nontreated) control cultures. $D-F$ show parallel views of LY294002-treated neurons. Arrowheads point to a representative apoptotic neuron with a degraded soma containing a condensed, fragmented nucleus labeled by TUNEL. Scale bar, $30 \mu \mathrm{m}$.

NGF-deprived sympathetic neurons. These include the protein synthesis inhibitor cycloheximide and the RNA synthesis inhibitor actinomycin D (Martin et al., 1988), cell-permeable cAMP analogs (Rydel and Greene, 1988), the cyclin-dependent kinase inhibitor flavopiridol (Park et al., 1996), membrane-depolarizing concentrations of extracellular potassium (Koike et al., 1989), and the nonselective caspase inhibitor BAF (Deshmukh et al., 1996). We tested several of these agents for their ability to inhibit LY294002-induced death (Fig. 3). The addition of either BAF $(100 \mu \mathrm{M})$ or cpt-cAMP $(300 \mu \mathrm{M})$ in large part prevented the death of LY294002-treated neurons. The addition of actinomycin D also provided protection from cell death, albeit to a lesser extent. Although the cell bodies of neurons rescued by BAF, cpt-cAMP, or actinomycin $\mathrm{D}$ remained phase-bright with clearly discernible nuclei and nucleoli, significant neuritic degeneration continued to occur in these cultures (data not shown), suggesting that the mechanisms that maintain neurite integrity may be distinct from those that control cell survival. In contrast to the above reagents, flavopiridol $(1 \mu \mathrm{M})$ provided little protection against LY294002induced death, whereas LY294002 treatment of potassiumdepolarized neurons resulted in even greater cell death than exposure to LY294002 in the presence of NGF. The ability of cpt-cAMP, BAF, and actinomycin D to prevent death caused either by NGF withdrawal or LY294002 suggests that both treatments activate a similar cell death pathway.

Withdrawal of NGF from sympathetic neurons results in in- creased mRNA expression of a select subset of genes, including c-jun, c-fos, and cyclin D1 (Estus et al., 1994; Freeman et al., 1994). RT-PCR analysis of mRNAs isolated from LY294002treated and nontreated cultures demonstrated that the expression of c-fos, c-jun, and cyclin D1 increases during LY294002-induced death (Fig. 4). Whereas $c$-jun expression exhibited a relatively constant prolonged elevation, $c$-fos expression increased sharply between 25 and $30 \mathrm{hr}$. cyclin D1 message levels exhibited a sustained elevation (three- to fourfold), peaking after $30 \mathrm{hr}$ of treatment. As expected, LY294002 treatment led to a reduction in the abundance of the ubiquitously expressed cyclophilin mRNA and in the neuronally expressed tyrosine hydroxylase and $\mathrm{p} 75$ neurotrophin receptor mRNAs. Unlike NGF deprivation (Freeman et al., 1994), LY294002 treatment resulted in a steady decrease in the mRNA level of the Schwann cell marker S100 $\beta$, suggesting that LY294002 also may be detrimental to certain non-neuronal cells present at low levels in these cultures. The induction of $c$-fos, $c$-jun, and cyclin D1 during neuronal death induced by inhibiting PI 3-kinase or by the withdrawal of NGF provides further evidence that LY294002-induced death and NGF deprivation-induced death share a common mechanism.

\section{NGF-stimulated Akt protein kinase activity is blocked by PI 3-kinase inhibitors}

The Akt protein kinase is activated by a variety of growth factors via a PI 3-kinase-dependent pathway (Burgering and Coffer, 
A

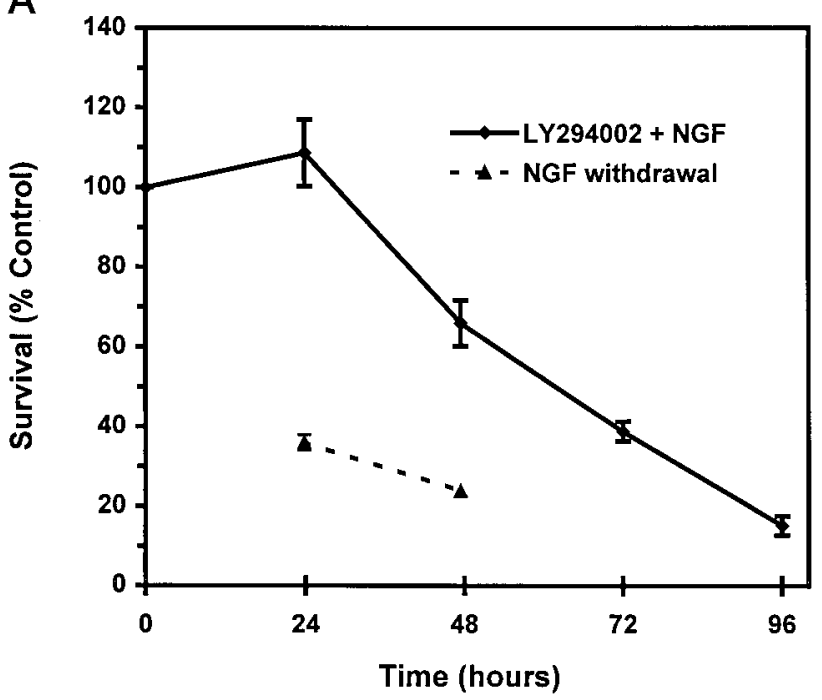

B

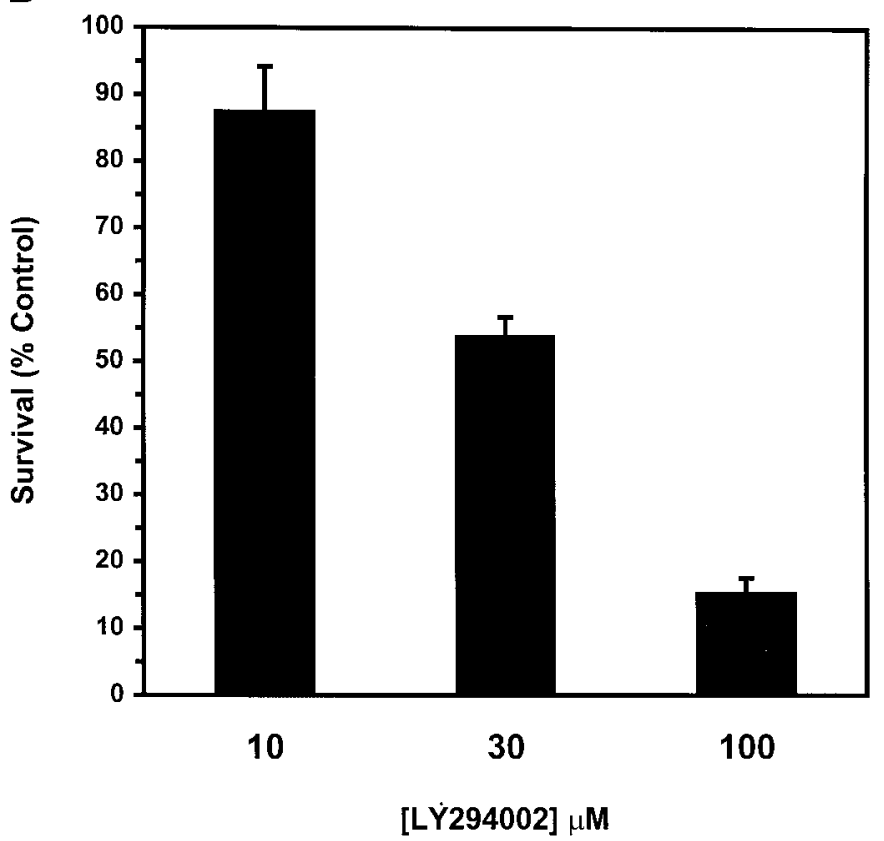

Figure 2. Death of sympathetic neurons by LY294002 is time- and dose-dependent. $A$, The $5 \mathrm{~d}$ neuronal cultures were treated with $100 \mu \mathrm{M}$ LY294002 in AM50 or were deprived of NGF. Survival was assayed at 24, 48, 72, and $96 \mathrm{hr}$ after a single application of LY294002 or after 24 and 48 hr of NGF deprivation by counting Nissl-stained neurons. Results represent mean \pm SEM from three independent experiments. $B$, The $5 \mathrm{~d}$ cultures were treated with a single dose of 10,30 , or $100 \mu \mathrm{M} \mathrm{LY} 294002$ in AM50. Survival was assayed after $4 \mathrm{~d}$ by counting Nissl-stained neurons, as described in Materials and Methods. The $100 \mu \mathrm{M}$ LY294002 treatment data are the same as those shown in $A$. Results represent the mean \pm SEM from three independent experiments and are presented as a percentage of the survival in control NGF-maintained cultures.

1995; Cross et al., 1995; Franke et al., 1995; Kohn et al., 1995; Klippel et al., 1996). Akt has been implicated in transducing growth factor and extracellular matrix-dependent survival signals in fibroblast, epithelial, and lymphoid cell lines (Ahmed et al., 1997; Kauffmann-Zeh et al., 1997; Kennedy et al., 1997; Khwaja et al., 1997; Kulik et al., 1997). Recently, a role for Akt also has been defined in the survival of rat cerebellar granule neurons

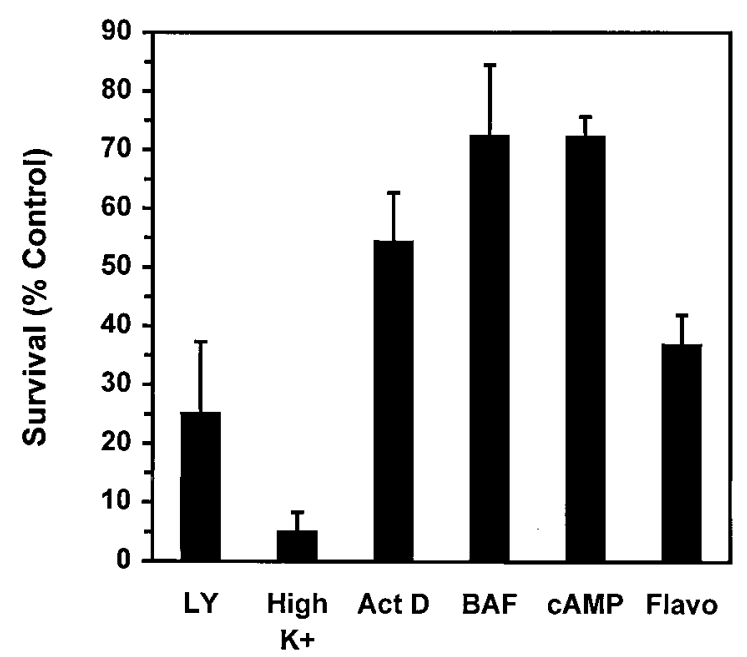

Figure 3. BAF, cpt-cAMP, and actinomycin D inhibit LY294002induced death. The $5 \mathrm{~d}$ cultures maintained in AM50 were treated with $100 \mu \mathrm{M} L Y 294002$ alone $(L Y)$ or in the presence of each of the following: $1 \mu \mathrm{M}$ flavopiridol (Flavo), $0.1 \mu \mathrm{g} / \mathrm{ml}$ actinomycin D (ActD), $100 \mu \mathrm{M}$ BAF $(B A F)$, or $300 \mu \mathrm{M}$ cpt-cAMP $(c A M P)$. For one set of treatments the neurons maintained in depolarizing concentrations of potassium without NGF were treated with $100 \mu \mathrm{M}$ LY294002 $\left(\mathrm{High} \mathrm{K}^{+}\right)$. Neuronal survival was assayed after $80 \mathrm{hr}$ by counting Nissl-stained neurons. In control experiments each agent effectively prevented the death of NGF-deprived neurons (data not shown). Results represent the mean \pm range from two independent experiments and are presented as a percentage of the survival in control NGF-maintained cultures.

(Dudek et al., 1997). To assess a potential function for Akt in NGF-mediated survival of sympathetic neurons, we first tested whether endogenous Akt protein kinase activity is stimulated in neurons treated with $\mathrm{NGF}$, using histone $\mathrm{H} 2 \mathrm{~B}$ as an in vitro substrate (Fig. 5). After 15 min of NGF stimulation, Akt protein kinase activity increased approximately threefold above the basal level observed in the absence of NGF. Treatment with $100 \mu \mathrm{M}$ LY294002 (or $100 \mathrm{~nm}$ wortmannin; data not shown) reduced the NGF-stimulated kinase activity to the level observed in NGFdeprived neurons. In contrast, treatment of neurons with $10 \mu \mathrm{M}$ LY294002 caused only a partial (50-60\%) reduction in NGFstimulated Akt kinase activity (data not shown). Thus, NGF treatment leads to the activation of endogenous Akt protein kinase activity in sympathetic neurons, which can be blocked by inhibitors of PI 3-kinase at concentrations similar to those that block survival.

\section{Expression of activated PI 3-kinase or activated Akt prevents the death of NGF-deprived neurons}

The results described above indicate that NGF stimulates a PI 3-kinase-regulated pathway that leads to Akt activation. To test whether the activation of this pathway in the absence of NGF would be sufficient to promote neuronal survival, we microinjected sympathetic neurons with plasmid DNAs expressing either a constitutively active form of PI 3-kinase (p110*) or a kinaseinactive mutant (p110* $\Delta$ kin) (Hu et al., 1995; Kulik et al., 1997) (Fig. 6). Indirect immunofluorescence analysis of microinjected neurons verified that $\mathrm{p} 110^{*}$ and $\mathrm{p} 110^{*} \Delta$ kin were overexpressed successfully in $85-90 \%$ of injected cells. After $48 \mathrm{hr}$ of NGF deprivation, most neurons injected with p110* maintained a phase-bright cell soma with uniformly dispersed chromatin and intact neurites (Fig. 7 $A-C$ ). In contrast, the majority of neurons injected with $\beta$-galactosidase (LacZ) or p110* $\Delta$ kin and then 


\section{LY294002 Treatment (h)}

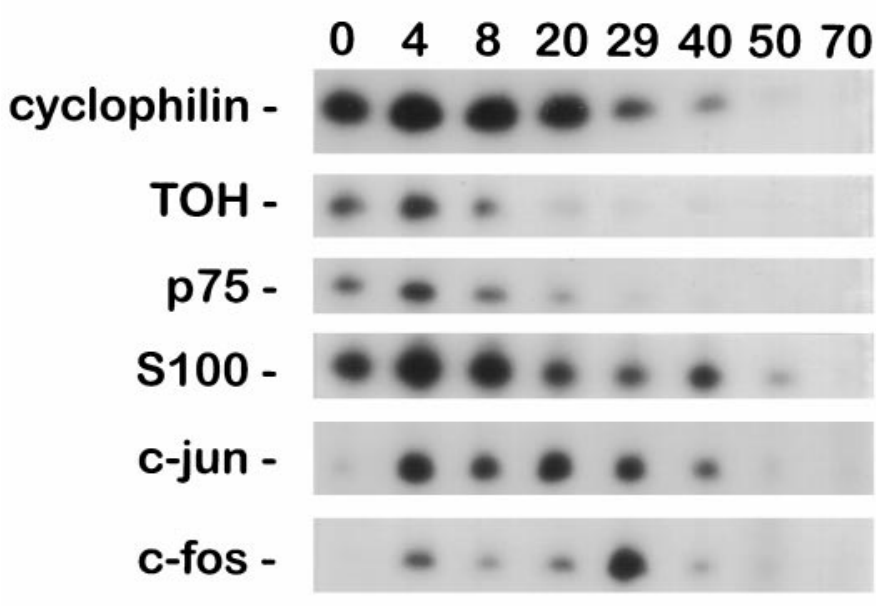

Cyclin D1 -

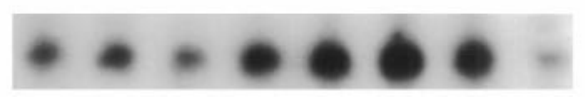

Figure 4. Expression of cyclin D1, c-jun, and c-fos increase during LY294002-induced death. Neurons cultured in AM50 for $5 \mathrm{~d}$ received no treatment $(0 \mathrm{hr})$ or were treated with $100 \mu \mathrm{M} \mathrm{LY} 294002$ in AM50 for the indicated time intervals. Relative changes in the mRNA levels of specific genes were measured by semiquantitative RT-PCR analysis, as outlined in Materials and Methods. Shown are representative results from one of three independent time courses, all of which yielded similar results. PCR cycle numbers for each of the genes were as follows: cyclophilin, 18 cycles; tyrosine hydroxylase $(\mathrm{TOH}), 18$ cycles; $\mathrm{p} 75$ neurotrophin receptor $(p 75)$, 18 cycles; $c$-fos, 24 cycles; $c$-jun, 24 cycles; cyclin D1, 25 cycles; S100 $\beta, 28$ cycles.

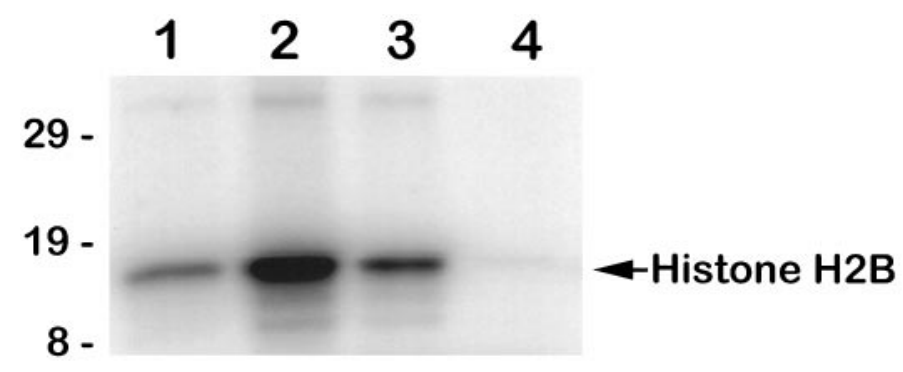

Figure 5. NGF stimulates Akt protein kinase activity in a PI 3-kinasedependent manner. Akt protein kinase activity was analyzed in immune complex kinase assays prepared from SCG neurons treated as follows: lane 1, neurons deprived of NGF for $10 \mathrm{hr}$; lane 2, neurons deprived of NGF for $10 \mathrm{hr}$ and then stimulated with NGF for $15 \mathrm{~min}$; lane 3, neurons deprived of NGF for $10 \mathrm{hr}$ and then treated with NGF for $15 \mathrm{~min}$ in the presence of $100 \mu \mathrm{M}$ LY294002; lane 4, mock kinase reaction containing only histone $\mathrm{H} 2 \mathrm{~B},\left[\gamma^{32} \mathrm{P}\right] \mathrm{ATP}$, and protein A beads. Reaction products were analyzed by SDS-PAGE, followed by autoradiography and PhosphorImager analysis. Akt protein kinase activity increased an average of 3.1-fold after NGF stimulation $(n=4)$.

deprived of NGF were morphologically indistinguishable from uninjected NGF-deprived cells and either contained condensed chromatin or lacked detectable chromatin (Fig. 7D-F). Quantifying the cell survival (see Materials and Methods) revealed that expression of $\mathrm{p} 110 *$ resulted in the survival of $78 \%$ of injected neurons after $48 \mathrm{hr}$ of NGF deprivation (Fig. 8). Survival of p $110^{*} \Delta$ kin or LacZ-injected neurons was 17 and $25 \%$, respectively, which was similar to the survival of uninjected NGFdeprived neurons. These data indicate that PI 3-kinase activity is
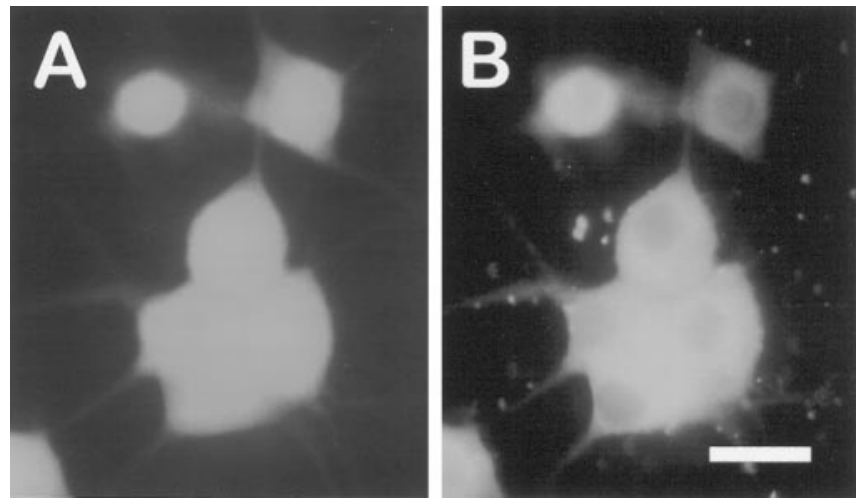

Figure 6. Constitutively active PI 3-kinase (p110*) is expressed efficiently in microinjected sympathetic neurons. Neurons were injected with p110* plasmid and lysine-fixable tetramethylrhodamine-dextran. At $15 \mathrm{hr}$ after microinjection the neurons were fixed and stained with the 9E10 monoclonal antibody, which recognizes the myc epitope attached to p110*. The 9E10 antibody was detected by FITC-conjugated anti-mouse antibodies. $A$ shows rhodamine-labeled (injected) cells. $B$, Immunofluorescence analysis shows that all of the injected neurons in $A$ overexpress p110*. Overall, p110* was detected in $90 \%$ of the injected neurons. Scale bar, $30 \mu \mathrm{m}$.

sufficient to promote the survival of sympathetic neurons in the absence of NGF.

Akt activation involves the binding of D3 phosphoinositides, the products of PI 3-kinase, to the N-terminal pleckstrin homology $(\mathrm{PH})$ domain of Akt. This is thought to localize Akt to the cell membrane where subsequent phosphorylation of regulatory serine and threonine residues occurs (Alessi et al., 1996; Kohn et al., 1996b; Franke et al., 1997; Klippel et al., 1997). Accordingly, a form of Akt lacking its PH domain but containing a membranetargeting Src myristoylation sequence at its $\mathrm{N}$ terminus (myr$\mathrm{Akt}$ ) is constitutively active in the absence of stimuli normally required for PI 3-kinase activation (Kohn et al., 1996a,b). To examine whether activated Akt is sufficient for neuronal survival, we expressed myr-Akt or a version of myr-Akt containing an inactive myristoylation signal (A2myr-Akt) in SCG neurons and then removed NGF from the culture medium (Fig. 9). Expression of myr-Akt resulted in the survival of $77 \%$ of injected neurons after $48 \mathrm{hr}$ of NGF deprivation, as compared with $23 \%$ survival for control injections. A2myr-Akt provided an intermediate, but significant, level of protection (46\% survival) against NGF withdrawal. Thus, overexpression of activated forms of either PI 3-kinase or Akt protein kinase effectively prevents the death of NGF-deprived neurons. These results raise the possibility that NGF promotes the survival of sympathetic neurons, at least in part, via a PI 3-kinase-regulated pathway that involves Akt.

\section{Dominant negative forms of PI 3-kinase and Akt induce neuronal death in the presence of NGF}

Although LY294002 and wortmannin induce apoptosis in NGFmaintained neurons, the specific targets of these drugs, at the concentrations used here, cannot be identified. As an independent means of addressing whether PI 3-kinase is required for NGF-mediated survival, we microinjected NGF-maintained neurons with a plasmid expressing a dominant negative form of PI 3-kinase. The PI 3-kinase enzyme activated by tyrosine kinase receptors such as TrkA consists of a p110 catalytic subunit and a p85 regulatory subunit. The dominant negative mutant $(\Delta \mathrm{p} 85)$ contains a deletion within the inter-SH2 domain of p85 that abolishes its binding to $\mathrm{p} 110$, but not to growth factor receptors 

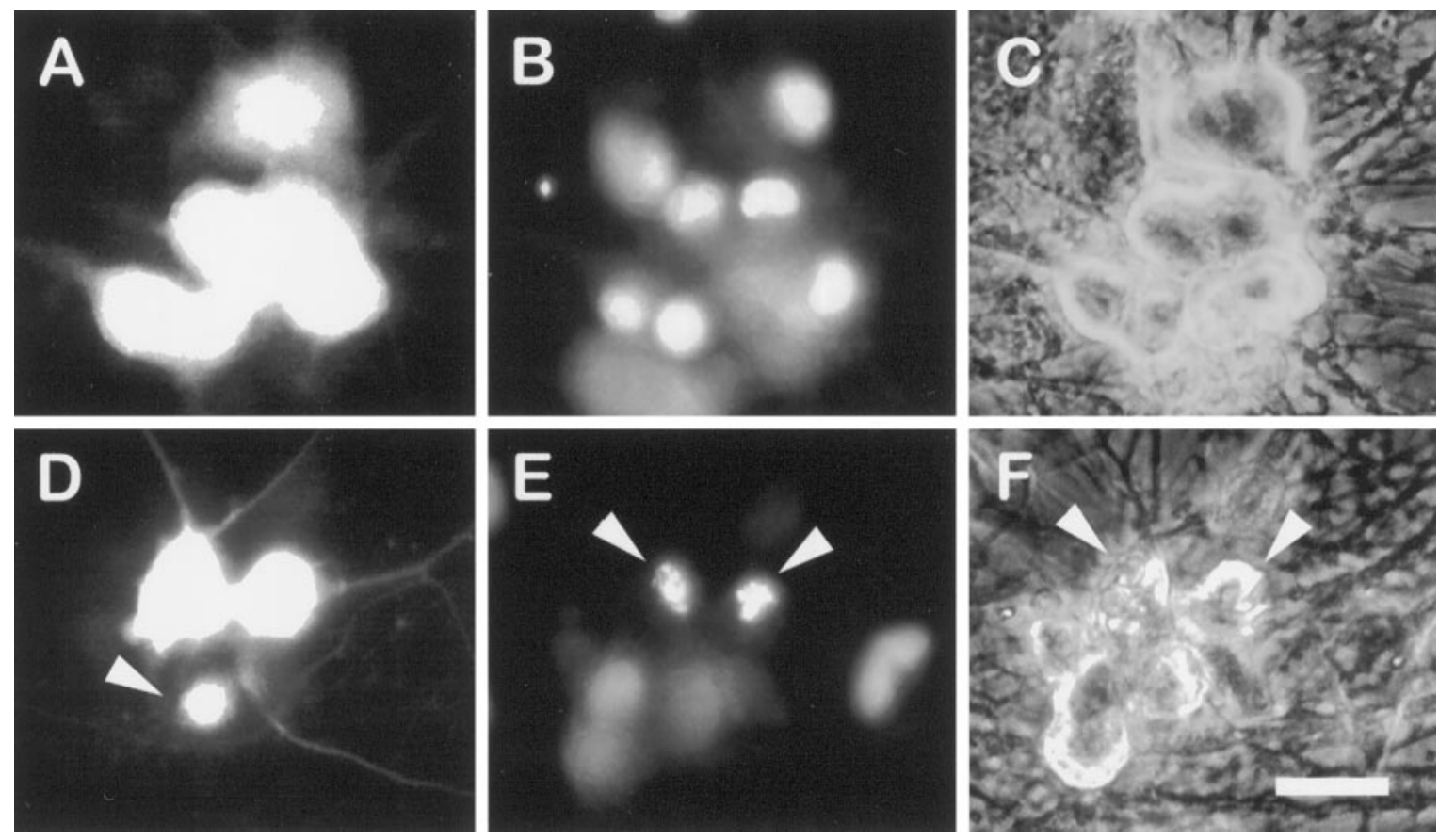

Figure 7. Overexpression of constitutively active PI 3-kinase is sufficient to promote the survival of NGF-deprived sympathetic neurons. Shown are photomicrographs of NGF-deprived neurons injected with $\mathrm{p} 110^{*}(A-C)$ or $\mathrm{p} 110^{*} \Delta \mathrm{kin}(D-F)$ expression vectors. Neurons were microinjected with the appropriate expression vectors, allowed to recover in AM50 for 12-15 hr, and then deprived of NGF for 48 hr. Neurons were stained with Hoechst dye and photographed. Photographs show rhodamine (injected cells) $(A, D)$, Hoechst-stained nuclei $(B, E)$, and phase-contrast views $(C, F)$ of one field of cells for each injected DNA. Cells scored as alive in these experiments retained spherical, phase-bright cell bodies, intact neurites, and uniformly dispersed chromatin $(A-C)$. Dead cells were characterized by phase-dark somas, fragmented neurites, and nuclear remnants devoid of stained chromatin or nuclei containing highly condensed chromatin $(D-F)$. The arrowhead in $D$ points to the remnant of a cell devoid of a nucleus. The arrowheads in $E$ and $F$ indicate phase-dark cells containing condensed chromatin. Scale bar, $40 \mu \mathrm{m}$.

(Dhand et al., 1994; Hara et al., 1994). Thus, $\Delta$ p85 competes with wild-type p85 for binding to activated receptors, but it is unable to induce p110 catalytic activity. Expression of $\Delta$ p 85 in neurons maintained in the presence of NGF resulted in a significant decrease in survival, as compared with control neurons microinjected with a LacZ expression vector (Fig. 10A). These data, together with the results obtained by using PI 3-kinase inhibitors, indicate that PI 3-kinase is required for the survival of sympathetic neurons by NGF.

Expression of either a truncated form of Akt consisting of residues 1-147 (AH-Akt) or a kinase-inactive Akt mutant (AktK179A) induces cell death in insulin-treated cerebellar granule cells and adherent epithelial cells (Dudek et al., 1997; Khwaja et al., 1997). In these studies the dominant negative nature of the mutants was demonstrated by a reduction in growth factorstimulated Akt kinase activity that occurred in cells cotransfected with mutant and wild-type Akt. To test whether Akt is necessary for NGF-promoted survival, we microinjected NGF-maintained neurons with expression plasmids containing either an epitopetagged version of AH-Akt or AktK179A (Fig. 10B). Expression of either AH-Akt or AktK179A in the presence of NGF substantially increased the number of apoptotic neurons, as compared with control neurons expressing LacZ. The extent of cell death in neurons expressing AH-Akt or AktK179A in the presence of NGF was slightly greater than that observed in neurons treated with LY294002 for 3 d (see Fig. 2). In control experiments the expression of AktK179A did not affect cell death caused by NGF deprivation. These results show that Akt, in addition to PI 3-kinase, is required for NGF-mediated neuronal survival.

\section{DISCUSSION}

Recent studies have implicated PI 3-kinase as an intracellular transducer of survival signals initiated by various growth factors. We began this study by asking whether PI 3-kinase also functions in the NGF-dependent survival of primary neurons. We found that neuronal death caused by inhibition of PI 3-kinase shares several features with death caused by NGF deprivation, suggesting that PI 3-kinase may function as an essential mediator of survival in NGF-dependent neurons. Consistent with this, expression of activated PI 3-kinase rescues NGF-deprived neurons from cell death, whereas expression of dominant negative PI 3-kinase blocks survival in the presence of NGF. NGF treatment of neurons activates Akt, a putative effector of PI 3-kinase, and Akt activation is dependent on PI 3-kinase. Expression of dominant negative forms of Akt block NGF-promoted survival, whereas expression of activated Akt is sufficient for survival in the absence of NGF. Taken together, these results identify Akt as an important mediator of PI 3-kinase-dependent survival signals initiated by NGF in sympathetic neurons.

The neuronal death caused by PI 3-kinase inhibitors resembles, in part, the death caused by NGF withdrawal, suggesting that both stimuli may activate similar cell death pathways. In both cases the death exhibits features characteristic of apoptosis, including cellular atrophy, chromatin condensation, TUNEL reactivity, and neurite fragmentation. The caspase inhibitor BAF and the RNA synthesis inhibitor actinomycin D block death caused by either treatment, suggesting a shared requirement for caspase activation and certain transcriptional events. Likewise, cpt-cAMP treatment blocks death caused by PI 3-kinase inhibition or NGF 


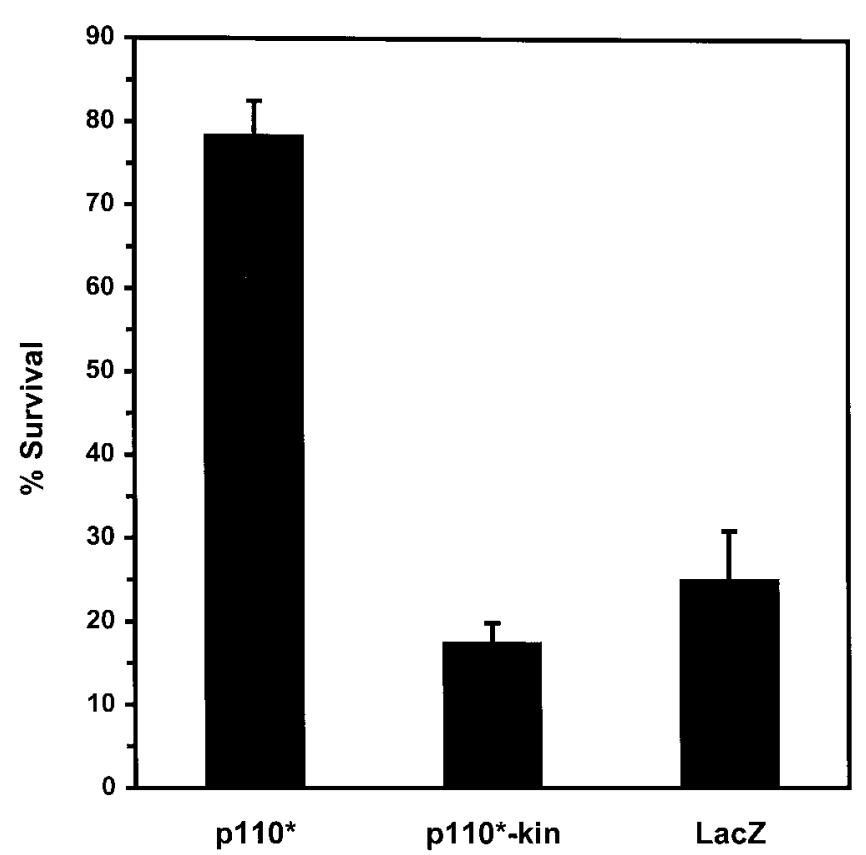

Figure 8. Quantitation of neuronal survival mediated by constitutively active PI 3-kinase. Neurons cultured in AM50 for 5-6 d were microinjected with expression vectors for p110*, p110* $\Delta$ kin, and LacZ and then deprived of NGF for $48 \mathrm{hr}$. Survival was assayed by a blinded observer in accordance with the criteria described above. Error bars represent the mean \pm SEM from four independent experiments. Survival for each of the following injections was $\mathrm{p} 110^{*}, 78.3 \pm 4.3 \%$; $110 * \Delta \mathrm{kin}, 17.3 \pm 2.5 \%$; and LacZ, $25.7 \pm 5.9 \%$. Survival with p110*-injected cells was significantly greater than $\mathrm{p} 110 * \Delta \mathrm{kin}$-injected or LacZ-injected cells (two-tailed $p$ values $=0.0001$ and 0.0003 , respectively). Survival between $110 * \Delta$ kin and LacZ was not significantly different $(p>0.35)$.

withdrawal, indicating the presence of a cAMP-mediated survival pathway that is independent or downstream of PI 3-kinase. Death caused by either treatment is accompanied by increased expression of $c$-jun, $c$-fos, and cyclin D1, with maximal gene expression persisting longer after PI 3-kinase inhibition, as compared with NGF withdrawal; this is consistent with the delayed time course of LY294002-induced death (see below).

Although LY294002 and wortmannin are selective inhibitors of PI 3-kinase, the use of these drugs does not permit positive identification of their target in sympathetic neurons. The concentrations of LY294002 and wortmannin that are required to induce apoptosis efficiently in this and other systems are also capable of inhibiting the activity of several members of the PI 3-kinase superfamily. Among these are the tyrosine kinase-activated p85/ p110 PI 3-kinases, heterotrimeric G-protein-stimulated p110 $\gamma$, and the mammalian target of rapamycin (mTOR) kinase (Stephens et al., 1994; Hartley et al., 1995; Brunn et al., 1996). Of these, only p85/p110 PI 3-kinase is known to be activated by NGF (Carter and Downes, 1992; Raffioni and Bradshaw, 1992). Moreover, rapamycin (0.01-100 nM) does not block the survival of NGF-maintained sympathetic neurons (R. Freeman, unpublished observation), suggesting that mTOR is not necessary for NGFmediated survival. Finally, the expression of a dominant negative mutant of p85 blocked NGF-promoted survival. Thus, although we cannot exclude the possibility of other effects, the inhibitors used in this study most likely inhibit the activation of p85/p110 PI 3-kinase by NGF.

Expression of activated PI 3-kinase or activated Akt is suffi-

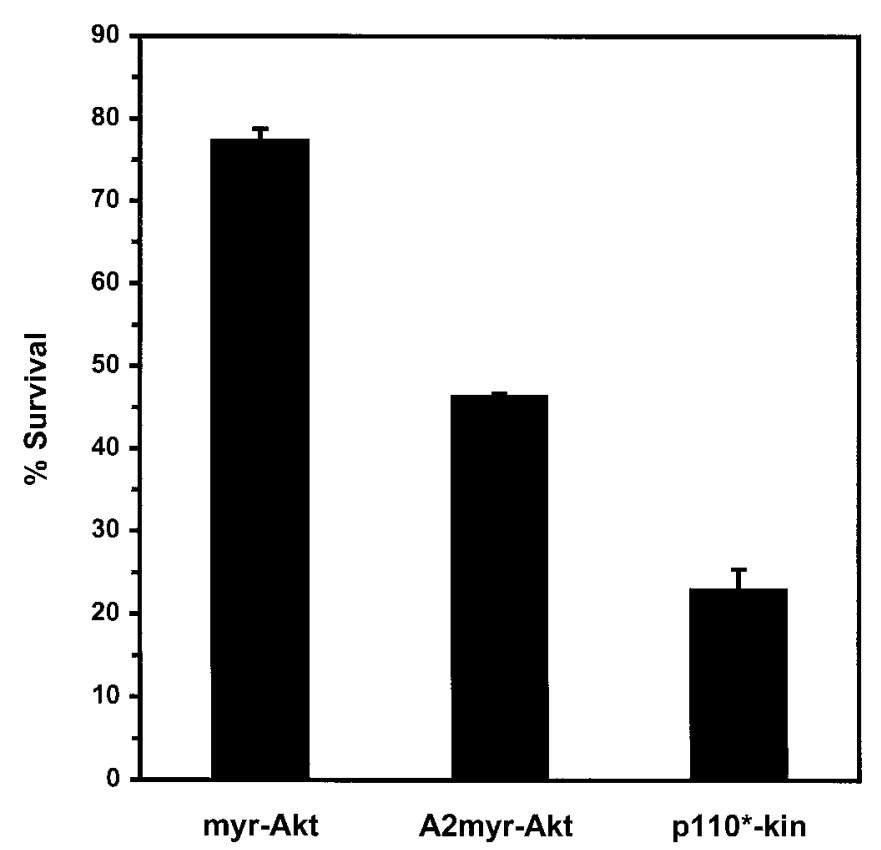

Figure 9. Overexpression of activated Akt (myr-Akt) is sufficient to promote the survival of NGF-deprived sympathetic neurons. Neurons cultured in AM50 for 5-6 d were microinjected with myr-Akt, A2myr$\mathrm{Akt}$, or $\mathrm{p} 110^{*} \Delta \mathrm{kin}$ (used as a negative control) expression vectors and then deprived of NGF for $\sim 48 \mathrm{hr}$. Then the injected cells were evaluated for survival. Error bars represent the mean \pm SEM from three independent experiments. Survival for each of the following injections was myr$\mathrm{Akt}, 77.4 \pm 1.3 \%$; A2myr-Akt, $46.5 \pm 0.26 \%$; and p110* $\Delta \mathrm{kin}, 23.2 \pm$ $2.4 \%$. Survival with myr-Akt-injected cells was significantly greater than for both A2myr-Akt-injected and p110* $\Delta$ kin-injected cells (two-tailed $p$ values $=2.1 \times 10^{-5}$ and $3.8 \times 10^{-5}$, respectively). Survival between A2myr-Akt and p110* $\Delta$ kin was also significantly different $(p=0.0006)$.

cient to keep neurons alive in the absence of NGF. The degree of saving conferred by activated PI 3-kinase and activated Akt is similar to that obtained by overexpressing the Bcl-2 protein in sympathetic neurons (Garcia et al., 1992; Greenlund et al., 1995b) (R. Crowder, unpublished observation). The form of PI 3-kinase that we used consists of the p110 catalytic subunit of PI 3-kinase fused at its $\mathrm{N}$ terminus to the inter-SH2 domain of the p85 regulatory subunit. Although expression of this and similar forms of activated PI 3-kinase can suppress apoptosis under certain conditions (Kauffmann-Zeh et al., 1997; Kennedy et al., 1997; Khwaja et al., 1997; Kulik et al., 1997), the mechanism by which this occurs is poorly characterized. When the activated form of PI 3-kinase used in our experiments was transiently expressed in COS-7 cells, Akt and pp $70^{\text {S6 }}$ kinase were activated constitutively in the absence of growth factor stimulation $(\mathrm{Hu}$ et al., 1995; Klippel et al., 1996). Although it is not known whether the expression of activated PI 3-kinase in neurons leads to activation of Akt, our data indicating that Akt is sufficient for survival in the absence of NGF and necessary for NGF-dependent survival suggest that Akt activation may be a critical event.

The activated form of Akt used in our experiments lacks its phospholipid-binding PH domain but is targeted to the cell membrane via a myristoylation sequence added to its $\mathrm{N}$ terminus (Kohn et al., 1996b). In fibroblasts, COS-7 cells, and cerebellar granule cells the overexpression of Akt or membrane-targeted forms of Akt also inhibit cell death (Dudek et al., 1997; Kauffmann-Zeh et al., 1997; Kennedy et al., 1997; Kulik et al., 1997). In these studies full-length Akt (with its PH domain intact) 
A

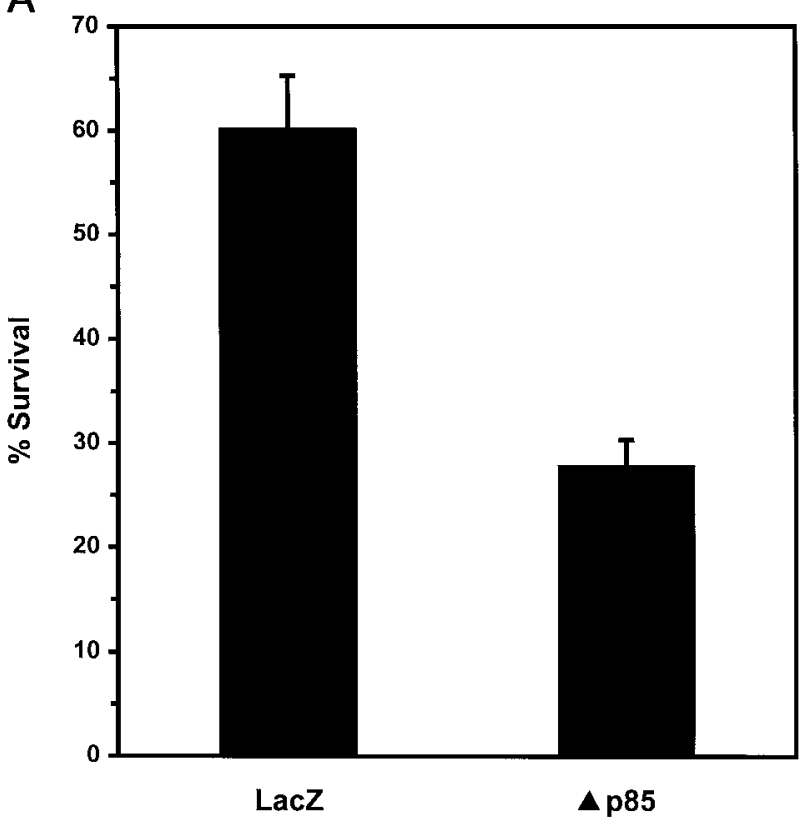

B

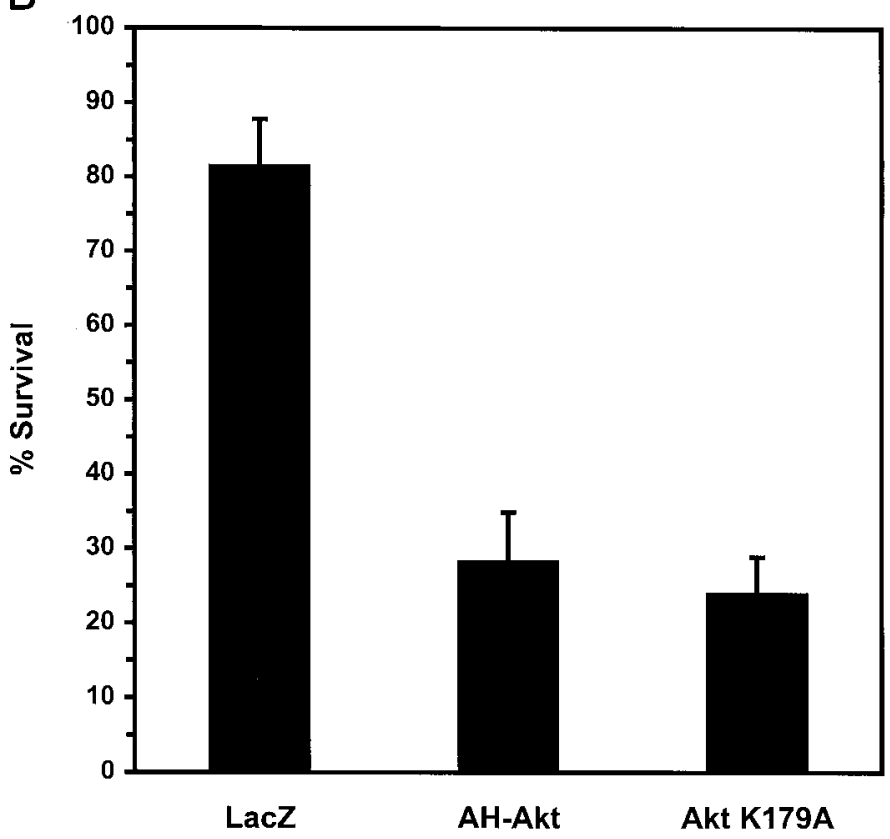

Figure 10. Expression of dominant negative PI 3-kinase ( $\Delta p 85)$, kinaseinactive Akt $(A k t K 179 A)$, or a truncated dominant negative Akt $(A H-$ $A k t)$ inhibits NGF-mediated neuronal survival. Neurons cultured in AM50 for 5-6 d were microinjected with LacZ or $\Delta \mathrm{p} 85(A)$ or LacZ, AH-Akt·Flag, or AktK179A expression vectors $(B)$ and then maintained in AM50 media for $3 \mathrm{~d}$. Then the injected cells were evaluated for survival. $A$, Survival was $60.2 \pm 5.2 \%$ and $27.9 \pm 2.5 \%$ for $\mathrm{LacZ}$ and $\Delta \mathrm{p} 85$, respectively (two-tailed $p$ value $=0.001$ ). Error bars represent the mean \pm SEM from four independent experiments. $B$, Survival for the following injections were LacZ, $81.6 \pm 6.3 \%$; AH-Akt, $28.4 \pm 6.7 \%$; and AktK179A, $24.1 \pm 4.9 \%$. Error bars represent the mean \pm SEM from four experiments for $\mathrm{LacZ}$ and AH-Akt and three experiments for AktK179A. Survival of AH-Akt-injected or AktK179A-injected neurons was significantly less than the survival of LacZ-injected cells (two-tailed $p$ value $=0.001$ ). Survival between AH-Akt and AktK179A was not significantly different $(p=0.65)$. was expressed rather than the PH domain-minus form used in our experiments. Assuming that the survival that occurs after expression of myr-Akt (lacking the $\mathrm{PH}$ domain) is not dependent on endogenous wild-type Akt, then the binding of phospholipids or other interactions mediated by the $\mathrm{PH}$ domain would not appear to be necessary for myr-Akt to promote survival in neurons.

The ability of activated Akt to prevent apoptosis after NGF withdrawal, taken together with the increase in Akt kinase activity that occurs after NGF stimulation, suggests that Akt may function to transduce NGF-initiated survival signals in neurons. To demonstrate more directly a role for Akt in NGF-mediated survival, we tested the effects of functionally inhibiting Akt with dominant negative mutants of Akt. Expression of either the $\mathrm{N}$-terminal AH domain of Akt or a kinase-inactive Akt mutant blocked survival promotion by NGF. Because activation of Akt by NGF is prevented by LY294002 and wortmannin, these results identify Akt as a downstream target of PI 3-kinase and TrkA in the survival-promoting pathway initiated by NGF.

Although our studies demonstrate a role for Akt and PI 3-kinase in survival, they do not rule out the possibility that NGF activates additional survival pathways. The delayed onset of cell death, the slower rate of death, and the prolonged expression of c-jun and cyclin D1 caused by inhibitors of PI 3-kinase (relative to NGF withdrawal) may indicate that other survival pathways not affected by LY294002 or wortmannin might be downregulated after the removal of NGF. Turning off such pathways by withdrawing NGF could lead to faster cell death by (1) more completely inactivating the PI 3-kinase pathway than is possible with LY294002 or wortmannin in this system or (2) inactivating additional or alternative survival pathways. Studies in PC12 cells suggest that certain MAP kinases, in particular the extracellular signal-regulated kinases (ERKs), may be important for survival mediated by NGF or other growth factors (Xia et al., 1995). However, recent studies using sympathetic neurons demonstrate that inhibitors of MAP kinase kinase-1, an upstream activator of ERKs, do not block NGF-mediated survival (Creedon et al., 1996; Virdee and Tolkovsky, 1996), suggesting that ERK activation may be dispensable for survival promotion by NGF. Previous studies have implicated a Ras-dependent pathway in the NGFmediated survival of chick sensory neurons (Borasio et al., 1989, 1993) and rat sympathetic neurons (Nobes and Tolkovsky, 1995; Nobes et al., 1996). In both cases the introduction of Rasneutralizing antibodies into dissociated neurons blocks survival in the presence of NGF, whereas the introduction of activated Ras results in NGF-independent survival. Known or putative effectors of Ras include the Raf/MAP kinase pathway, PI 3-kinase, Ral-GDS, and the Ras-related small GTPases, Rac and cdc42 (Marshall, 1996). Because both Ras and PI 3-kinase now have been implicated in survival promotion by NGF and because PI 3-kinase is a possible effector of Ras (Rodriguez-Viciana et al., 1994, 1997), these two proteins may lie within the same survival pathway.

Besides inactivating additional survival molecules, NGF withdrawal may lead to the activation of proapoptotic pathways that either are not activated or are activated incompletely after PI 3-kinase inhibition. JNK and the related kinase p38 are critical mediators of apoptosis in NGF-deprived PC12 cells (Xia et al., 1995). JNK also is activated after NGF withdrawal in sympathetic neurons, and c-Jun, a target of JNK and p38 phosphorylation, is required for neuronal death caused by NGF withdrawal (Estus et al., 1994; Ham et al., 1995; Virdee et al., 1997). Activation of JNK or p38 by NGF withdrawal, but not after inhibition of PI 3-kinase, 
could contribute to the increased rate of death caused by withdrawal of NGF.

In summary, our results suggest that survival of sympathetic neurons mediated by NGF is dependent on a PI 3-kinase and Akt-regulated pathway. Other relevant participants in this survival pathway are unknown but could include Ras, phosphatidylinositol-dependent kinase-1 (Alessi et al., 1997), and two downstream targets of Akt-glycogen synthase kinase-3 (Cross et al., 1995) and Bad (Datta et al., 1997; del Peso et al., 1997).

\section{REFERENCES}

Ahmed NN, Grimes HL, Bellacosa A, Chan TO, Tsichlis PN (1997) Transduction of interleukin-2 antiapoptotic and proliferative signals via Akt protein kinase. Proc Natl Acad Sci USA 94:3627-3632.

Alessi DR, Andjelkovic M, Caudwell B, Cron P, Morrice N, Cohen P, Hemmings BA (1996) Mechanism of activation of protein kinase B by insulin and IGF-1. EMBO J 15:6541-6551.

Alessi DR, James SR, Downes CP, Holmes AB, Gaffney PRJ, Reese CB, Cohen P (1997) Characterization of a 3-phosphoinositide-dependent protein kinase which phosphorylates and activates protein kinase B-alpha. Curr Biol 7:261-269.

Barbacid M (1994) The Trk family of neurotrophin receptors. J Neurobiol 25:1386-1403.

Borasio GD, John J, Wittinghofer A, Barde YA, Sendtner M, Heumann R (1989) Ras p21 protein promotes survival and fiber outgrowth of cultured embryonic neurons. Neuron 2:1087-1096.

Borasio GD, Markus A, Wittinghofer A, Barde YA, Heumann R (1993) Involvement of ras p21 in neurotrophin-induced response of sensory, but not sympathetic neurons. J Cell Biol 121:665-672.

Brunn GJ, Williams J, Sabers C, Wiederrecht G, Lawrence Jr JC, Abraham RT (1996) Direct inhibition of the signaling functions of the mammalian target of rapamycin by the phosphoinositide 3-kinase inhibitors, wortmannin and LY294002. EMBO J 15:5256-5267.

Burgering BM, Coffer PJ (1995) Protein kinase B (c-Akt) in phosphatidylinositol-3-OH kinase signal transduction. Nature 376: 599-602.

Carter AN, Downes CP (1992) Phosphatidylinositol 3-kinase is activated by nerve growth factor and epidermal growth factor in PC12 cells. J Biol Chem [Erratum (1992) 267:23434] 267:14563-14567.

Creedon DJ, Johnson Jr EM, Lawrence JC (1996) Mitogen-activated protein kinase-independent pathways mediate the effects of nerve growth factor and cAMP on neuronal survival. J Biol Chem 271:20713-20718.

Cross DA, Alessi DR, Cohen P, Andjelkovic M, Hemmings BA (1995) Inhibition of glycogen synthase kinase- 3 by insulin mediated by protein kinase B. Nature 378:785-789.

Crowley C, Spencer SD, Nishimura MC, Chen KS, Pitts-Meek S, Armanini, MP, Ling LH, MacMahon SB, Shelton DL, Levinson AD, Phillips HS (1994) Mice lacking nerve growth factor display perinatal loss of sensory and sympathetic neurons yet develop basal forebrain cholinergic neurons. Cell 76:1001-1011.

Datta SR, Dudek H, Tao X, Masters S, Fu H, Gotoh Y, Greenberg ME (1997) Akt phosphorylation of BAD couples survival signals to the cell-intrinsic death machinery. Cell 91:231-241.

Deckwerth TL, Johnson Jr EM (1993) Temporal analysis of events associated with programmed cell death (apoptosis) of sympathetic neurons deprived of nerve growth factor (NGF). J Cell Biol 123:1207-1222.

del Peso L, González-García M, Page C, Herrera R, Nuñez G (1997) Interleukin-3-induced phosphorylation of BAD through the protein kinase Akt. Science 278:687-689.

Deshmukh M, Vasilakos J, Deckwerth TL, Lampe PA, Shivers BD, Johnson Jr EM (1996) Genetic and metabolic status of NGF-deprived sympathetic neurons saved by an inhibitor of ICE family proteases. J Cell Biol 135:1341-1354.

Dhand R, Hara K, Hiles I, Bax B, Gout I, Panayotou G, Fry MJ, Yonezawa K, Kasuga M, Waterfield MD (1994) PI 3-kinase: structural and functional analysis of intersubunit interactions. EMBO J 13:511-521.

D’Mello SR, Borodezt K, Soltoff SP (1997) Insulin-like growth factor and potassium depolarization maintain neuronal survival by distinct pathways: possible involvement of PI 3-kinase in IGF-1 signaling. J Neurosci 17:1548-1560.

Dudek H, Datta SR, Franke TF, Birnbaum MJ, Yao R, Cooper GM, Segal RA, Kaplan DR, Greenberg ME (1997) Regulation of neuronal survival by the serine/threonine protein kinase Akt. Science 275:661-665.

Edwards SN, Tolkovsky AM (1994) Characterization of apoptosis in cultured rat sympathetic neurons after nerve growth factor withdrawal. J Cell Biol 124:537-546.

Estus S, Zaks WJ, Freeman RS, Gruda M, Bravo R, Johnson Jr EM (1994) Altered gene expression in neurons during programmed cell death: identification of $c$-jun as necessary for neuronal apoptosis. J Cell Biol 127:1717-1727.

Ferrari G, Greene LA (1994) Proliferative inhibition by dominantnegative Ras rescues naive and neuronally differentiated PC12 cells from apoptotic death. EMBO J 13:5922-5928.

Franke TF, Yang SI, Chan TO, Datta K, Kazlauskas A, Morrison DK, Kaplan DR, Tsichlis PN (1995) The protein kinase encoded by the Akt proto-oncogene is a target of the PDGF-activated phosphatidylinositol 3-kinase. Cell 81:727-736.

Franke TF, Kaplan DR, Cantley LC, Toker A (1997) Direct regulation of the Akt proto-oncogene product by phosphatidylinositol-3,4bisphosphate. Science 275:665-668.

Freeman RS, Estus S, Johnson Jr EM (1994) Analysis of cell cyclerelated gene expression in postmitotic neurons: selective induction of cyclin D1 during programmed cell death. Neuron 12:343-355.

Garcia I, Martinou I, Tsujimoto Y, Martinou J-C (1992) Prevention of programmed cell death of sympathetic neurons by the bcl-2 protooncogene. Science 258:302-304.

Gavrieli Y, Sherman Y, Ben-Sasson SA (1992) Identification of programmed cell death in situ via specific labeling of nuclear DNA fragmentation. J Cell Biol 119:493-501.

Greenlund LJS, Deckwerth TL, Johnson Jr EM (1995a) Superoxide dismutase delays neuronal apoptosis: a role for reactive oxygen species in programmed neuronal death. Neuron 14:303-315.

Greenlund LJS, Korsmeyer SJ, Johnson Jr EM (1995b) Role of BCL-2 in the survival and function of developing and mature sympathetic neurons. Neuron 15:649-661.

Ham J, Babij C, Whitfield J, Pfarr CM, Lallemand D, Yaniv M, Rubin LL (1995) A c-jun dominant negative mutant protects sympathetic neurons against programmed cell death. Neuron 14:927-939.

Hara K, Yonezawa K, Sakaue H, Ando A, Kotani K, Kitamura T, Kitamura Y, Ueda H, Stephens L, Jackson TR, Hawkins PT, Dhand R, Clark AE, Holman GD, Waterfield MD, Kasuga M (1994) 1-Phosphatidylinositol 3-kinase activity is required for insulinstimulated glucose transport but not for Ras activation in $\mathrm{CHO}$ cells. Proc Natl Acad Sci USA 91:7414-7419.

Hartley KO, Gell D, Smith GC, Zhang H, Divecha N, Connelly MA, Admon A, Lees-Miller SP, Anderson CW, Jackson SP (1995) DNAdependent protein kinase catalytic subunit: a relative of phosphatidylinositol 3-kinase and the ataxia telangiectasia gene product. Cell 82:849-856.

Hendry IA, Campbell J (1976) Morphometric analysis of rat superior cervical ganglion after axotomy and nerve growth factor treatment. J Neurocytol 5:351-360

Hu Q, Klippel A, Muslin AJ, Fantl WJ, Williams LT (1995) Rasdependent induction of cellular responses by constitutively active phosphatidylinositol-3 kinase. Science 268:100-102.

Kaplan DR, Stephens RM (1994) Neurotrophin signal transduction by the Trk receptor. J Neurobiol 25:1404-1417.

Kaplan DR, Martin-Zanca D, Parada LF (1991) Tyrosine phosphorylation and tyrosine kinase activity of the trk proto-oncogene product induced by NGF. Nature 350:158-160.

Kauffmann-Zeh A, Rodriguez-Viciana P, Ulrich E, Gilbert C, Coffer P, Downward J, Evan G (1997) Suppression of c-Myc-induced apoptosis by Ras signaling through PI(3)K and PKB. Nature 385:544-548.

Kennedy SG, Wagner AJ, Conzen SD, Jordan J, Bellacosa A, Tsichlis PN, Hay N (1997) The PI 3-kinase/Akt signaling pathway delivers an antiapoptotic signal. Genes Dev 11:701-713.

Khwaja A, Rodriguez-Viciana P, Wennstrom S, Warne PH, Downward J (1997) Matrix adhesion and Ras transformation both activate a phosphoinositide 3-OH kinase and protein kinase B/Akt cellular survival pathway. EMBO J 16:2783-2793.

Klein R, Jing SQ, Nanduri V, O'Rourke E, Barbacid M (1991) The trk 
proto-oncogene encodes a receptor for nerve growth factor. Cell 65:189-197.

Klippel A, Reinhard C, Kavanaugh WM, Apell G, Escobedo MA, Williams LT (1996) Membrane localization of phosphatidylinositol 3-kinase is sufficient to activate multiple signal-transducing kinase pathways. Mol Cell Biol 16:4117-4127.

Klippel A, Kavanaugh WM, Pot D, Williams LT (1997) A specific product of phosphatidylinositol 3-kinase directly activates the protein kinase Akt through its pleckstrin homology domain. Mol Cell Biol $17: 338-344$.

Kohn AD, Kovacina KS, Roth RA (1995) Insulin stimulates the kinase activity of RAC-PK, a pleckstrin homology domain containing ser/thr kinase. EMBO J 14:4288-4295.

Kohn AD, Summers SA, Birnbaum MJ, Roth RA (1996a) Expression of a constitutively active Akt Ser/Thr kinase in 3T3-L1 adipocytes stimulates glucose uptake and glucose transporter 4 translocation. J Biol Chem 271:31372-31378.

Kohn AD, Takeuchi F, Roth RA (1996b) Akt, a pleckstrin homology domain containing kinase, is activated primarily by phosphorylation. J Biol Chem 271:21920-21926.

Koike T, Martin DP, Johnson Jr EM (1989) Role of $\mathrm{Ca}^{2+}$ channels in the ability of membrane depolarization to prevent neuronal death induced by trophic-factor deprivation: evidence that levels of internal $\mathrm{Ca}^{2+}$ determine nerve growth factor dependence of sympathetic ganglion cells. Proc Natl Acad Sci USA 86:6421-6425.

Konishi H, Shinomura T, Kuroda S, Ono Y, Kikkawa U (1994) Molecular cloning of rat RAC protein kinase alpha and beta and their association with protein kinase $\mathrm{C}$ zeta. Biochem Biophys Res Commun 205:817-825

Kotani K, Yonezawa K, Har K, Ueda H, Kitamura Y, Sakaue H, Ando A, Chavanieu A, Calas B, Grigorescu F, Nishiyama M, Waterfield MD, Kasuga M (1994) Involvement of phosphoinositide 3-kinase in insulinor IGF-1-induced membrane ruffling. EMBO J 13:2312-2321.

Kulik G, Klippel A, Weber MJ (1997) Antiapoptotic signaling by the insulin-like growth factor I receptor, phosphatidylinositol 3-kinase, and Akt. Mol Cell Biol 17:1595-1606.

Marshall CJ (1996) Ras effectors. Curr Opin Cell Biol 8:197-204.

Martin DP, Schmidt RE, DiStefano PS, Lowry OH, Carter JG, Johnson Jr EM (1988) Inhibitors of protein synthesis and RNA synthesis prevent neuronal death caused by nerve growth factor deprivation. J Cell Biol 106:829-844.

Martin DP, Ito A, Horigome K, Lampe PA, Johnson Jr EM (1992) Biochemical characterization of programmed cell death in NGFdeprived sympathetic neurons. J Neurobiol 23:1205-1220.

Miller TM, Tansey MG, Johnson Jr EM, Creedon DJ (1997) Inhibition of phosphatidylinositol 3-kinase activity blocks depolarization- and insulin-like growth factor 1-mediated survival of cerebellar granule cells. J Biol Chem 272:9847-9853.

Nobes CD, Tolkovsky AM (1995) Neutralizing anti-p21 ${ }^{\text {ras }}$ Fabs suppress rat sympathetic neuron survival induced by NGF, LIF, CNTF, and cAMP. Eur J Neurosci 7:344-350.

Nobes CD, Reppas JB, Markus A, Tolkovsky AM (1996) Active p21 Ras is sufficient for rescue of NGF-dependent rat sympathetic neurons. Neuroscience 70:1067-1079.

Obermeier A, Lammers R, Weismuller K-H, Jung G, Schlessinger J, Ullrich A (1993) Identification of Trk binding sites for SHC and phosphatidylinositol 3'-kinase and formation of a multimeric signaling complex. J Biol Chem 268:22963-22966.

Ohmichi M, Decker SJ, Pang L, Saltiel AR (1991) Nerve growth factor binds to the $140 \mathrm{kDa}$ trk proto-oncogene product and stimulates its association with the src homology domain of phospholipase C $\gamma 1$. Biochem Biophys Res Commun 179:217-223.

Oppenheim RW (1991) Cell death during development of the nervous system. Annu Rev Neurosci 14:453-501.

Park DS, Farinelli SE, Greene LA (1996) Inhibitors of cyclin-dependent kinases promote survival of postmitotic neuronally differentiated PC12 cells and sympathetic neurons. J Biol Chem 271:8161-8169.

Parrizas M, Saltiel AR, LeRoith D (1997) Insulin-like growth factor 1 inhibits apoptosis using the phosphatidylinositol 3'-kinase and mitogenactivated protein kinase pathways. J Biol Chem 272:154-161.

Raffioni S, Bradshaw RA (1992) Activation of phosphatidylinositol 3-kinase by epidermal growth factor, basic fibroblast growth factor, and nerve growth factor in PC12 pheochromocytoma cells. Proc Natl Acad Sci USA 89:9121-9125.

Rodriguez-Viciana P, Warne PH, Dhand R, Vanhaesebroeck B, Gout I, Fry MJ, Waterfield MD, Downward J (1994) Phosphatidylinositol3-OH kinase as a direct target of Ras. Nature 370:527-532.

Rodriguez-Viciana P, Warne PH, Khwaja A, Marte BM, Pappin D, Das P, Waterfield MD, Ridley A, Downward J (1997) Role of phosphoinositide 3-OH kinase in cell transformation and control of the actin cytoskeleton by Ras. Cell 89:457-467.

Rydel RE, Greene LA (1988) cAMP analogs promote survival and neurite outgrowth in cultures of rat sympathetic and sensory neurons independently of nerve growth factor. Proc Natl Acad Sci USA 85:1257-1261.

Smeyne RJ, Klein R, Schnapp A, Long LK, Bryant S, Lewin A, Lira SA, Barbacid M (1994) Severe sensory and sympathetic neuropathies in mice carrying a disrupted Trk/NGF receptor gene. Nature 368: $246-249$.

Soltoff SP, Rabin SL, Cantley LC, Kaplan DR (1992) Nerve growth factor promotes the activation of phosphatidylinositol 3-kinase and its association with the trk tyrosine kinase. J Biol Chem 267:17472-17477.

Stephens L, Smrcka A, Cooke FT, Jackson TR, Sternweis PC, Hawkins PT (1994) A novel phosphoinositide 3-kinase activity in myeloidderived cells is activated by G-protein beta gamma subunits. Cell 77:83-93.

Virdee K, Tolkovsky AM (1996) Inhibition of p42 and p44 mitogenactivated protein kinase activity by PD98059 does not suppress nerve growth factor-induced survival of sympathetic neurones. J Neurochem 67:1801-1805.

Virdee K, Bannister AJ, Hunt SP, Tolkovsky AM (1997) Comparison between the timing of JNK activation, c-Jun phosphorylation, and onset of death commitment in sympathetic neurons. J Neurochem 69:550-561.

Vlahos CJ, Matter WF, Hui KY, Brown RF (1994) A specific inhibitor of phosphatidylinositol 3-kinase, 2-(4-morpholinyl)-8-phenyl-4H-1benzopyran-4-one (LY294002). J Biol Chem 269:5241-5248.

Xia Z, Dickens M, Raingeaud J, Davis RJ, Greenberg ME (1995) Opposing effects of ERK and JNK-p38 MAP kinases on apoptosis. Science 270:1326-1331.

Yano H, Nakanishi S, Kimura K, Hanai N, Saitoh Y, Fukui Y, Nonomura Y, Matsuda Y (1993) Inhibition of histamine secretion by wortmannin through the blockade of phosphatidylinositol 3-kinase in RBL-2H3 cells. J Biol Chem 268:25846-25856.

Yao R, Cooper GM (1995) Requirement for phosphatidylinositol-3 kinase in the prevention of apoptosis by nerve growth factor. Science 267:2003-2006.

Yao R, Cooper GM (1996) Growth factor-dependent survival of rodent fibroblasts requires phosphatidylinositol 3-kinase but is independent of pp70S6K activity. Oncogene 13:343-351. 